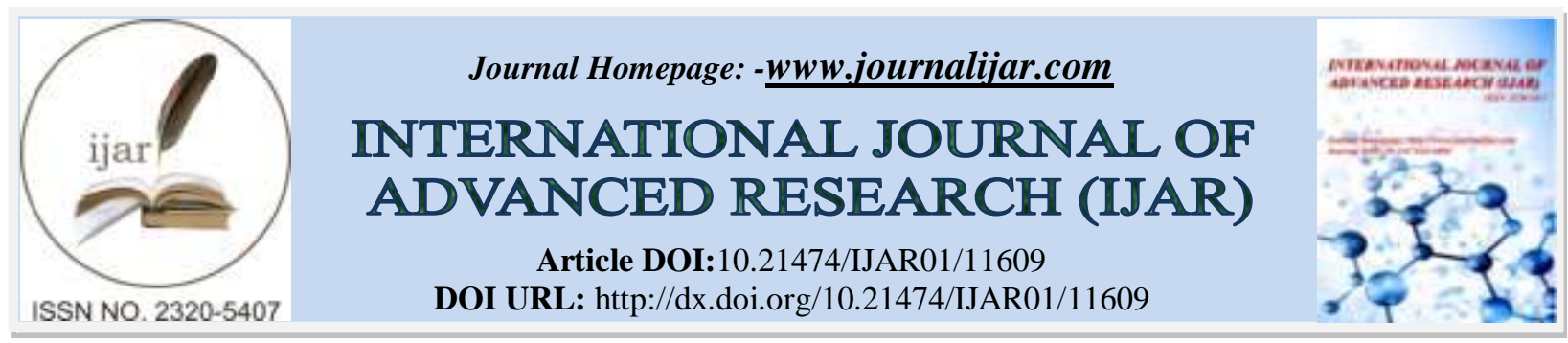

RESEARCH ARTICLE

\title{
UNRAVELING THE ECONOMIC DISPARITIES AND SIMILARITIES: THE CASE OF CANADA AND BANGLADESH
}

Drishti Agarwal

\section{Manuscript Info}

Manuscript History

Received: 30 June 2020

Final Accepted: 31 July 2020

Published: August 2020

\section{Abstract}

This paper explores the economic development of Canada and Bangladesh following their independence from the British Rule in 1982 and 1971, respectively. It dwells on various economic indicators to identify the causes of the divergence in the growth rates of both nations. Finally, the Solow Growth model is used to get an in-depth understanding of the countries' economic performances and determine their standard of living.

Copy Right, IJAR, 2020,. All rights reserved.

\section{Introduction:-}

Canada and Bangladesh, both liberated from the British Colonial rule like two phoenixes rising from the ashes, provide an interesting set of countries to discuss the drivers of economic growth. In the nationalist spree of excising imperialism, Bangladesh, initially, a part of India and Pakistan, became an independent nation in $1971^{1}$. Canada, on the other hand, adopted its own constitution and gained complete sovereignty in $1982^{2}$.

Given the fact that Bangladesh became independent a decade before Canada and that the British Empire ruled in Canada (1763-1982) for longer than it did in India (1858-1947), a critical question arises: how did Canada become one of the wealthiest nations in the world in such a short time, while Bangladesh remains one of the least developed countries in the world?

Canada lies on the continent of North America, stretching from the Pacific Ocean in the west to the Atlantic Ocean in the east and bordered by the United States in the south and the Arctic Ocean in the north. If you strolled through Ottawa, Canada's capital,, you would find yourself in the midst of a radiant and bustling city, with skyscrapers and small cafes and shops lined along cobbled streets. You would also be acquainted with Canada's multiculturalism policy (adopted by the government in the 1970s) ${ }^{3}$ as you observe diverse ethnicities of its people, such as Canadians (32.3\%), English (18.3\%), Scottish (13.9\%), and French (13.6\%), all of which contribute to the majority of Canada's population ${ }^{4}$. Looking at Canada holistically, it has unique geography, consisting of rocky mountains, lush green valleys, dense forests, vast expanses of lakes and rivers, and snowy polar regions towards the north. This varied geographical aspect along with Canada's multicultural values, undoubtedly makes it a center for tourism, a vital part of the Canadian economy ${ }^{5}$.

Bangladesh, located in South Asia, is bordered by India, Myanmar, and the Bay of Bengal. While it has a significantly smaller surface area, its geographical aspect is somewhat similar to that of Canada. Bangladesh is marked by lush greenery, dense forests, an extensive network of rivers and streams, marshy land, and a small hilly region. Additionally, the Sundarbans (an enormous mangrove forest which is home to the Royal Bengal tiger and diverse wildlife), is recognized as a UNESCO world heritage site ${ }^{6}$, therefore making Bangladesh a famous tourist destination. In terms of population and local ethnicity, it is quite different from Canada. Bangladesh's population is comprised of various religions, including Muslims (89.1\%), Hindus (10\%), Buddhists and Christians (together 
$0.9 \%)^{7}$. While there are a few commonalities and many disparities between the two countries based on culture, art, and religion, they are not enough to justify the large economic gap that persists between Canada and Bangladesh.

This section will look at some of the fundamental facts pertaining to the two countries. Canada has the secondlargest surface area in the world, close to 3,855,100 square miles ${ }^{8}$ and approximately 68 times larger than that of Bangladesh, which is about 57,000 square miles (World Bank, 2020). Bangladesh is highly populated, ranked 8th as the most populated country in the world, with roughly 161 million people. On the contrary, Canada is home to just approximately 37 million people. The GDP per capita of both nations is divergent, with Canada's at \$46,000 USD per capita, while Bangladesh's is only \$1,700 USD per capita. Looking at the frame of reference, it can be stated that Canada's level of development is similar to Germany, while Bangladesh's is akin to Pakistan, further emphasizing on their different growth levels.

Table 1:- GDP, Population, and Per capita GDP - Canada and Bangladesh - US\$.

\begin{tabular}{|l|l|l|l|l|l|l|l|}
\hline \multicolumn{9}{|l|}{ Canada } & \multicolumn{3}{l|}{ Bangladesh } \\
\hline Year & GDP & Population & P.C. GDP & Year & GDP & Population & P. C. GDP \\
\hline 1982 & $\$ 313.507$ & 25.117 & $\$ 12,481.9$ & 1971 & $\$ 8.752$ & 65.532 & $\$ 133.6$ \\
\hline 2018 & $\begin{array}{l}\$ 1,713.342 \\
\text { trillion }\end{array}$ & 37.058 & $\$ 46,234.4$ & 2018 & $\$ 274.025$ & 161.356 & $\$ 1698.3$ \\
\hline
\end{tabular}

Source: World Bank, GDP current US\$ (in Billions); Population (in Millions)

With analysis of these facts based on Adam Smith's Classical Growth theory, it can be postulated that Bangladesh's economic growth is negatively sloped due to its rapid population growth and limited resources such as natural gas, coal, timber, and petroleum. Overpopulation puts pressure on the finite resources of a country and eventually leads to resource depletion. Along those same lines, it can be theorized that Canada's rapid economic growth is because of its low population and a vast source of natural resources such as water, forests, natural gas, oil, etc. However, these conjectures are false because a myriad of factors have to be considered when judging a country's economic growth. Moreover, the conventional wisdom of "paradox of plenty" has proven that an abundance of natural resources does not always lead to increased economic growth. The Republic of Congo is one of the most prosperous countries in terms of affluence of natural resources ${ }^{9}$; however, its level of economic growth is quite low.

The objective of this paper is to compare and contrast Canada and Bangladesh's economic growth since their independence from British rule. The chronology is as follows: the following section provides a brief overview of the historical, political, and socio-economic scenario of both the territories. The third section will delve into their economic profiles and focus on the macro-economic indicators such as real GDP per capita and life expectancy. Next, the Solow Growth model will be used as an application to explain Canada's high economic growth and level of development. The fifth and final section will include policy recommendations for Bangladesh and summarise the findings of this research.

\section{Historical, political and socio-economic background:}

In the 1860s, the desire for a greater Canadian federation grew. This was due to multiple reasons, such as obtaining common defense, having a national railroad system, and reducing the rising conflicts between the British and the French. Thus, after tough negotiations and many conferences, on July 1, 1867, the Dominion of Canada was officially announced to act as an independent entity within the British Empire, with John Alexander Macdonald elected as the first Prime Minister. However, the road to gaining complete sovereignty was long and a winding one. In 1931, through the Statute of Westminster, the Dominion of Canada acquired full legal freedom and equal standing with England, but Britain still possessed the authority to alter Canada's constitution. During that time, after several changes and negotiations, Canada established its own national flag featuring the maple leaf. Finally, in 1982 Canada became completely independent and embraced its own constitution. Although it is still a part of the British Commonwealth and Elizabeth II is the queen of Canada, the monarch's role is ritualistic, and she does not intervene in the nation's self-governance. Today, Canada is known to be a federal state, a parliamentary democracy, and a constitutional monarchy.

Dating back to the 16th century, Canada's economy depended on primary sectors consisting of agriculture, mining, fishing, farming, and hunting. With the arrival of the French and then the British, its economy flourished due to rapid industrialization, technological advancements, and trade flexibility. As one of the richest countries in natural resources, it engaged in the fur, timber, minerals, and oil trades ${ }^{10}$. Even though in the 21 st century the Canadian 
economy is largely dependent on the service sector, its reliance on natural resources has helped the economy develop and still does in some regions of the country today.

A stable and efficient financial system is imperative for sustained economic growth. Banking in Canada commenced with the establishment of the Bank of Montreal in $1817^{11}$. Soon, many banks opened up and each regulated their own local bank notes as currency; however, this caused losses and ended with the closure of many banks. In 1867, the new government under the Dominion of Canada finally administered the official Canadian currency (the Canadian dollar) and a national banking system. The formation of the central bank, the Bank of Canada, in 1935 was also a vital step for the smooth functioning of the country's financial system ${ }^{12}$. Today, the banking system in Canada is globally regarded as one of the safest and most efficient. In 2017-2018, the World Economic Forum ranked Canada number 2 in the world for having the soundest banks, assigning it a value of 6.6 out of $7^{13}$.

In 1947, the British Raj ended in the Indian subcontinent with a partition, forming two separate countries: India and Pakistan. Pakistan was divided into two sides, east and west, with East Pakistan lying in the eastern province of Bengal, about 1000 miles away from West Pakistan. There was a lack of coordination and communication between the two parts of Pakistan. Moreover, East Pakistan was discriminated against economically and made politically weak by the dominant and superior West Pakistan. This made the citizens and Sheik Mujibur Rahman (leader of Awami League) of East Pakistan rebellious, culminating in the Bangladesh Liberation War of $1971^{14}$. Supported by India, Pakistan surrendered and Bangladesh was finally formed as an independent nation after 24 years of suffering.

After independence, Sheik Mujibur Rahman was chosen as the PM of Bangladesh. Before the new nation could build itself and grow, it was hit with natural disasters such as floods and famine. These were coupled with frequent state emergencies and escalating political instability due to the assassination of Sheik Mujib in $1975^{15}$. Thereafter, periods of relief and economic and political unrest fluctuated in Bangladesh. From 1991 onwards, when Begum Khaleda Zia became the first woman PM, Bangladesh began restoring peace and experienced economic growth. A proper parliamentary system was also restored after several attempts of military coups forming a regime of martial law. From 2009 to today, under Sheikh Hasina's (PM) leadership, Bangladesh has flourished and in 2018, successfully met all three eligibility criteria for graduation from UN's Least Developed Countries list ${ }^{16}$.

The Bangladeshi economy has always been largely dependent on agriculture which has led to major problems of seasonal unemployment among rural farmworkers and low quality of life. To tackle this problem, during the era of Pakistani administration, a policy of industrialization was implemented wherein the economy was focused on industries of raw materials like jute, cotton, hides, and skin. This scheme had two goals: to promote free enterprise in the private sector and to amplify the production of consumer goods in order to avoid dependence on imports. However, when Bangladesh was formed, the new government changed these policies and nationalized most enterprises. During that time period, seeds that could have led to economic prosperity were not nurtured properly. The decision to nationalize industries led to severe turmoil, and industrial production fell dramatically. Eventually, new policies were introduced and the old ones revised, which have made Bangladesh relatively economically stable and sound today.

While the financial system of Canada is highly rated, Bangladesh has a comparatively deficient and poorly structured one. In 1971, after it gained sovereignty, the existing Dhaka branch of the State Bank of Pakistan was designated as Bangladesh's central bank and started operating under the name of Bangladesh Bank ${ }^{17}$. The official currency- Bangladeshi Taka- was also designed and distributed by the Bangladesh Bank. In the movement of nationalization, the government had also taken ownership of all commercial banks, which ultimately resulted in failure. However, normalcy was soon revived with industrial growth resulting from privatization of industry. An interesting initiative by Muhammad Yunus was the formulation of Grameen Bank in $1976^{18}$. Its purpose was to provide microfinance (credit lent in a form of small loans) to the poor who were not served by traditional banks. Thus, this trend of giving out loans on reasonable terms successfully spread in Bangladesh, generating productive self-employment and aiding in economic growth, even though it was on a smaller scale.

In conclusion, both the countries faced trials and successions in their missions to become sovereign and improve economically, politically, and socially. While Canada might have faced greater obstacles in gaining freedom over a longer time, Bangladesh had innumerable problems which were in fact harder to overcome and some of which are still prevalent. 


\section{Economic profile:}

This section explores the economic contexts of Canada and Bangladesh in order to evaluate the strengths and weaknesses of their economies. Country performance indicators such as real GDP and life expectancy are considered in order to to get a better understanding of their economic conditions. The economic performance of both Bangladesh and Canada after their independence from the British Empire in 1971 and 1982 will be scrutinized. This will aid in finding conclusive reasons for the gap that prevails between their growth rates and therefore help construct policies to achieve development in Bangladesh.

After Canada gained its sovereignty in the 1980s, it was hit by a recession which led to greater unemployment, inflation, and interest rates ${ }^{19}$. Although it did not have a major impact on the Canadian economy, the newly independent nation formulated a national policy of market liberalism ${ }^{20}$ to overcome that phase of deflationary gap. The policy relied on Canada-US free trade, NAFTA free trade, market-based policies, and fiscal restraint. High tariffs on imported manufactured goods were also removed, reducing the protectionism that occurred for manufacturing industries. These were plausible solutions for the trade barriers previously imposed by Britain. Later on, as Canada shifted to a more service sector-oriented economy, it focused on implementing 'strategic integration' which promoted human capital development, building of a national telecommunications infrastructure linked with information technology, and free trade. Today, Canada is highly industrialised with one of the world's highest per capita income rates ${ }^{21}$.

As for Bangladesh, after achieving independence in 1971 it considered ways to grow and develop in an extremely challenging environment bombarded with scarce natural resources, a rapidly growing population, frequently occurring natural disasters, and major political havoc. The 1970s and 1980s witnessed an increase in government intervention and socialism which involved nationalisation of many industries ${ }^{22}$. While Bangladesh experienced massive growth in 1973 and 1981, with a 3.3\% and 7.2\% GDP growth rate (annual \%) ("World Development Indicators | DataBank", 2020), this growth was counterbalanced with a greater rise in the population growth rate ("World Development Indicators | DataBank", 2020). The 1990s were far better, and the economic policies were revised under the new government. Privatisation, a free market economy, and political stability invited foreign direct investments (FDIs) and enabled technological advancements. However, the country was heavily reliant on international aid, loans, and remittances from Bangladeshis working abroad which increased the country's external debt. In the 21st century, Bangladesh has seen massive improvement and is in the process of moving out of the UN's LDCs list ${ }^{23}$.

Figure 1 and Figure 2 illustrarte the changes in per capita gross domestic product (GDP) of Canada and Bangladesh, beginning from the year of their independence. The overall trend of Canada's GDP per capita is much higher than that of Bangladesh's and each year it is approximately 70 times greater. As seen in Figure 1, Canada witnessed major growth in per capita GDP in 1984 and until 2007 ("World Development Indicators | DataBank", 2020), after which it was hit by the 2007-2008 global financial crisis. Since then, its GDP per capita is rising, though not at the same rapid rate as between the 1990s and 2007.

\section{CANADA}

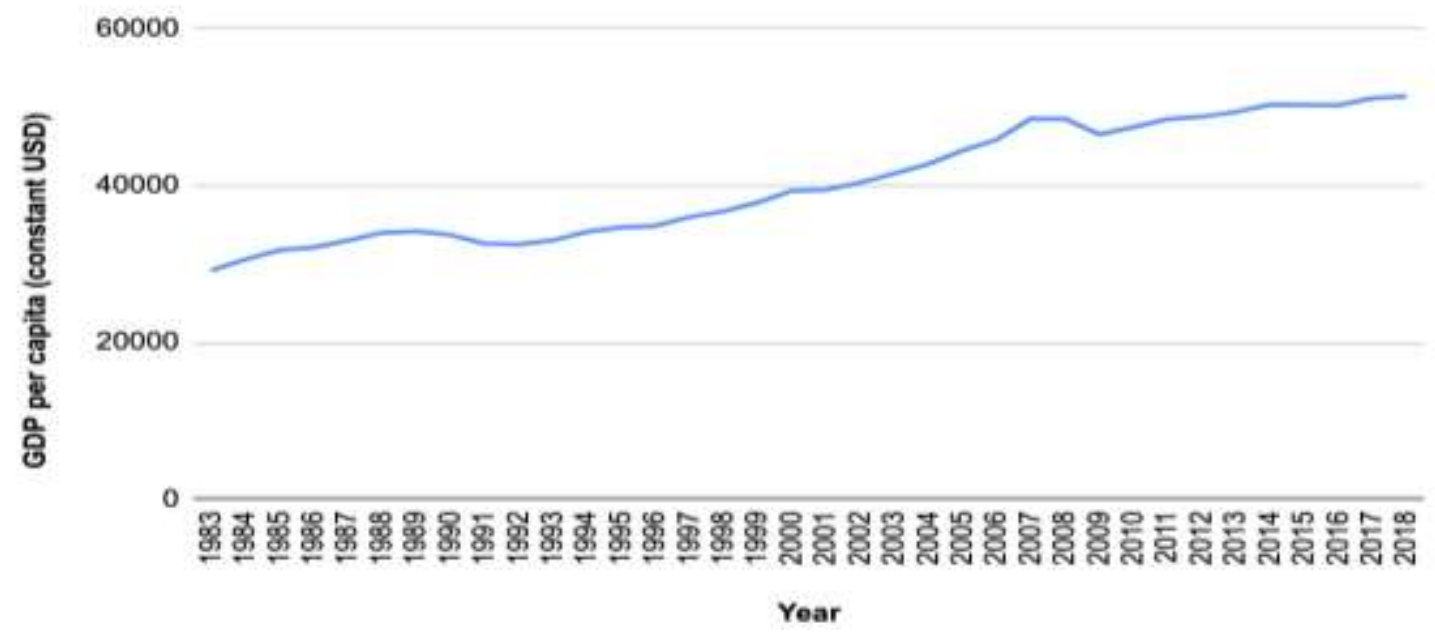

Figure 1:- GDP per capita (constant 2010 USD), Canada, 1982-2018 
Source: World Bank, GDP per capita in constant 2010 US\$, Canada

Bangladesh, on the other hand, has experienced an exponential increase in per capita GDP of its country after the 1990s, which is justified by an improvement in its political and economic condition as previously mentioned. The fluctuating nature of the GDP per capita curve, right after Bangladesh's independence due to political turbulence, natural calamities, and poor economic planning, is clearly displayed in Figure 2.
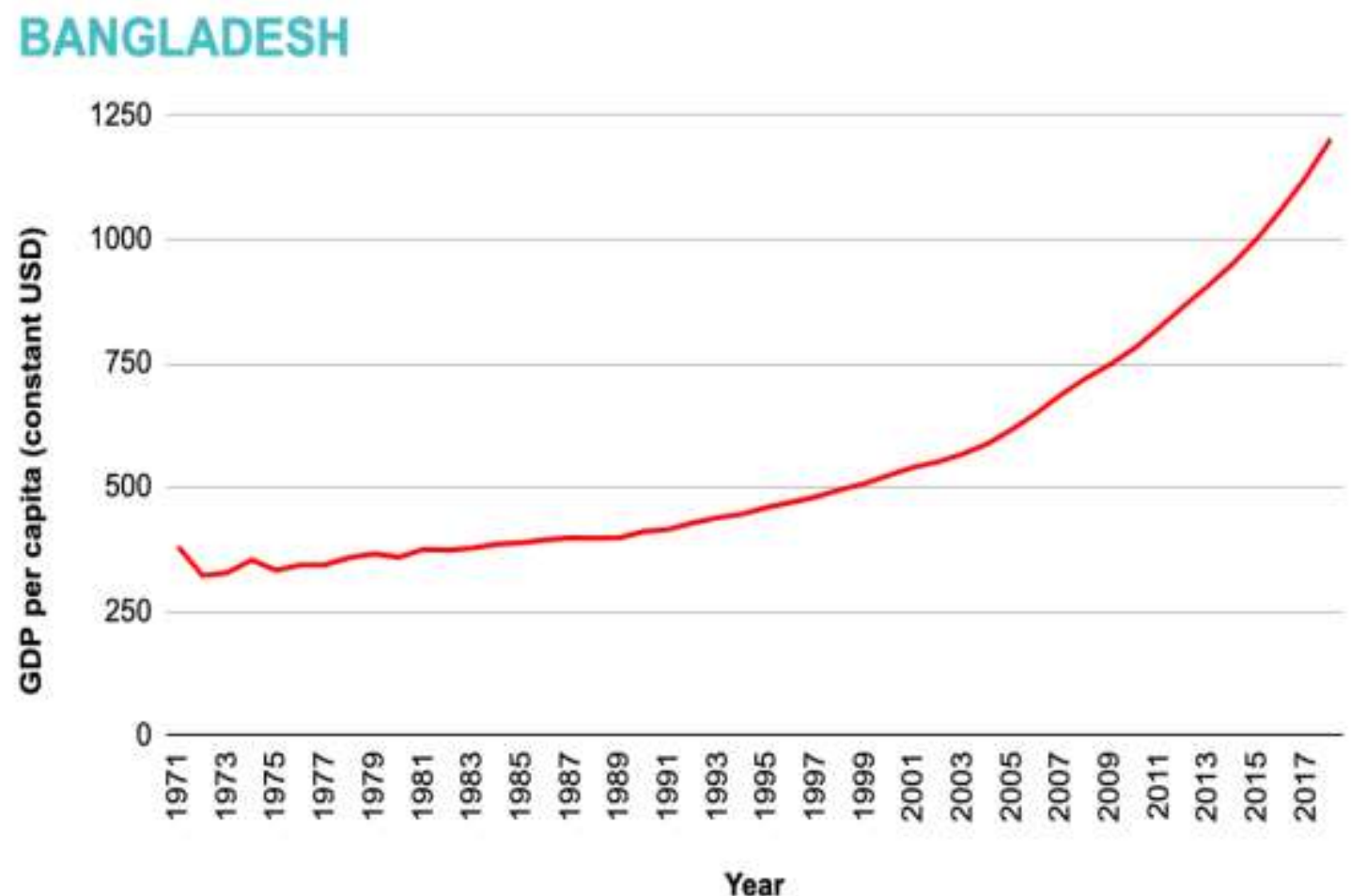

Figure 2:- GDP per capita (constant 2010 USD), Bangladesh, 1971-2018 Source: World Bank, GDP per capita in constant 2010 US\$, Bangladesh

Figure 3 below shows the trends in life expectancies at birth of the total population (in years) of Canada as well as Bangladesh since 1971. 'Life expectancy at birth' is a statistical measure that proxies the overall mortality level of a population and reflects on the country's economic development in terms of healthcare and standard of living.

Canada has undergone a steady, positively-sloped growth in life expectancy at birth, since 1982 and even before that. Its overall progression lies above that of Bangladesh's; in fact, the life expectancy at birth for both sexes in Canada has a current value of 82.96 , ranked 16th highest in the world ${ }^{24}$. On the contrary, after 1971, Bangladesh had a very low life expectancy measure valued at approx. 46.59 years, which is suggestive of the economy being underdeveloped and a lack of proper healthcare and sanitation facilities. Famine, war, and political instability are also the causes of Bangladesh's low life expectancy measure. However, Bangladesh's life expectancy at birth has grown rapidly, and the gap between the two curves has reduced and began to converge in the 21 st century. 


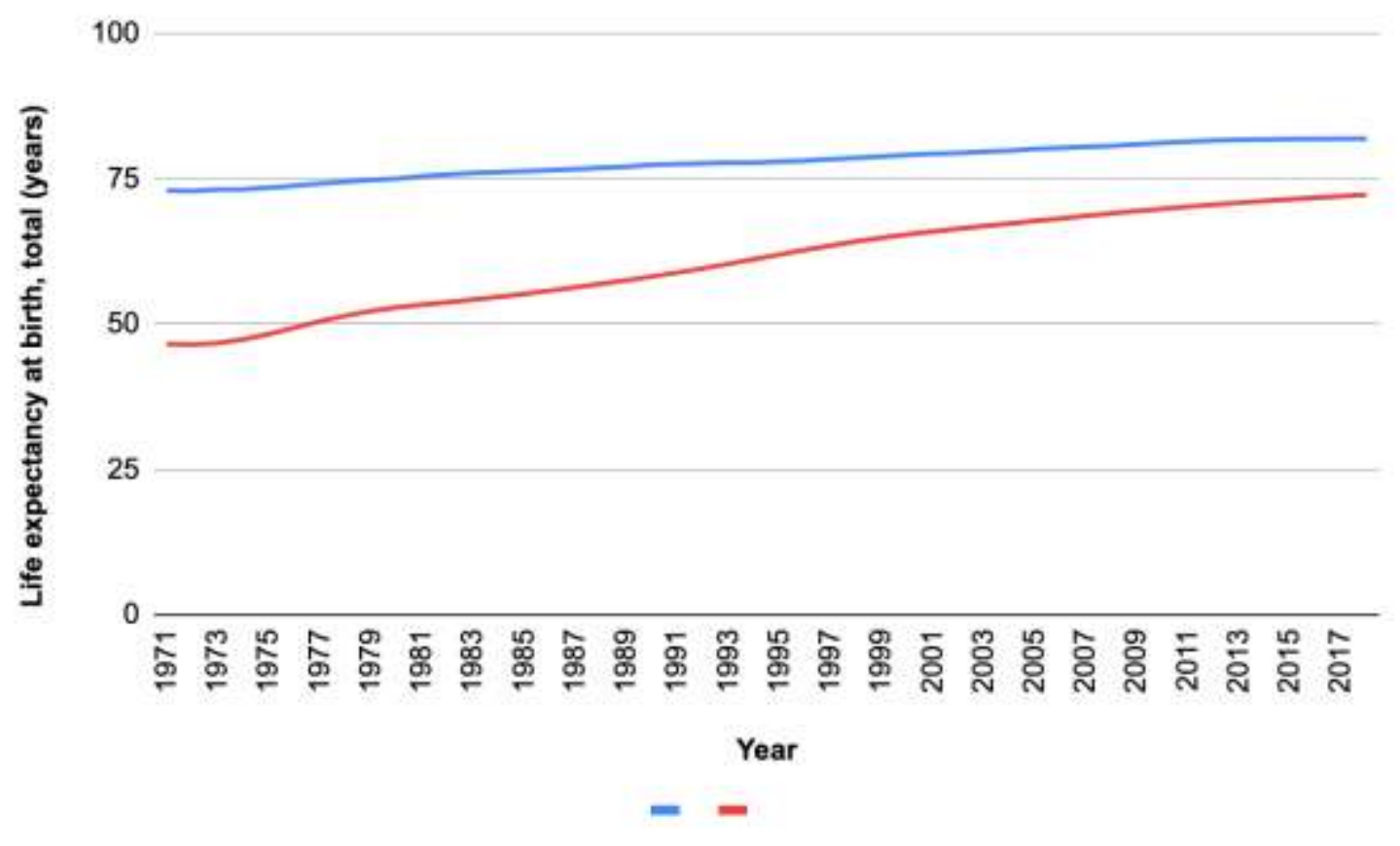

Figure 3:- Life expectancy at birth, total (years), Canada blue and Bangladesh bl, 1971-2018 Source: World Bank, Life expectancy at birth, total (years), Canada and Bangladesh

Comparing and evaluating the life expectancy chart in Figure 3 and the GDP per capita charts in Figures 1 and 2, it can be concluded that GDP per capita (per capita income) has an effect on life expectancy at birth and that they are correlated. At points where the per capita GDP for a country is significantly altering, the life expectancy graph for the same economy is also adjusting in the same manner. Traditionally, a higher per capita income would imply better access to healthcare services, housing, education, food supply, and other necessities which lead to a better quality of life, longevity, and thus, a high life expectancy at birth value.

According to the Preston curve $\mathrm{e}^{25}$, a theory formulated by the demographer Samuel H. Preston, it can be stated that individuals born in Canada (a wealthier country), on average, are more likely to live longer than those born in Bangladesh (poorer country). However, this is not mainly due to a rise in per capita income because high income inequality may exist, but a reduction in poverty. Canada's poverty rate has fallen from $12.4 \%$ in 2008 to $8.7 \%$ in $2018^{26}$, which is perhaps why it experienced a rise in the value of life expectancy. Similarly, Bangladesh is gradually catching up and its growth in life expectancy may be attributed to its remarkable progress in reducing poverty. Based on the international poverty line of $\$ 1.90$ (using purchasing power parity exchange rate) a day, it reduced poverty from 44.2 percent in 1991 to 14.8 percent in 2016/17 (World Bank "Overview", 2020). Thus, life expectancy at birth and per capita GDP seem to go hand in hand and are directly proportional.

The percentage of the primary, secondary, and tertiary sectors that contribute to a country's GDP (sector performance) also reflect on a country's economic growth and development. In the case of Canada, its early economy mainly consisted of agriculture, forestry, and fishing due to an abundance of natural resources and an absence of urbanisation and innovation. However, the statistics have transformed over the years; agriculture now employs less than $4 \%$ of the Canadian labor force ${ }^{27}$. Yet, it is important for the national economy, providing food and raw materials for the domestic and export market. The manufacturing sector accounted for around $17.5 \%$ of Canada's GDP in the late 1900s, but it has also witnessed a decline in the 21 st century, with a mere contribution of approximately 10.5\% in 2015 (World Bank, 2020). With better technologies and innovation, the manufacturing industries have become more advanced. The main manufacturing industries in Canada are automobile production, seafood processing, and meat processing. The service sector has accounted for more than $60 \%$ of Canada's GDP since the late 1900s (World Bank, 2020) and has grown to make up around 78\% of the GDP today. In recent years, services such as banking, tourism, communications, and real estate have significantly grown and become a major part of the service sector. Thus, a change in the sector contribution in the Canadian economy is a sign of economic 
development which is supported by the GDP data in Table 1. Comparing Bangladesh, it has the same distribution pattern as Canada's with the service sector adding up to make the greatest percentage of the GDP, followed by the manufacturing sector and then the agriculture sector. However, the difference lies in the amount of their contribution. As of 2018, the value added by agriculture, forest, and fishing sectors stands at $13.074 \%$ of Bangladesh's GDP (World Bank, 2020) and has declined from a value of 51.031\% in 1971. Rice, jute, and tea are the most dominant agricultural commodities; in fact, Bangladesh is one of the world's leading producers of raw jute. The secondary (manufacturing) sector has experienced rapid growth since 1971 and comprises 17.958\% of Bangladesh's GDP today (World Bank, 2020). Textile and clothing industries are the most vital part of the Bangladeshi economy. Like the secondary sector, the service sector has experienced the same growth trend and contributes approximately of $53 \%$ to GDP, with the tourism industry being the major contributor.

We now shift our attention to trade performance, which is another important indicator of economic growth and performance. Canada's economy has always been centered on trade, and it has partially been the reason behind Canada's massive economic growth. In the 1970s, the Canadian economic historian Harold Innis developed the 'Staple Thesis ${ }^{28}$, which has given a resource-enriched economy like Canada, a path to procure economic growth by using and exporting its staple products and natural resources. Different regions in Canada produce different staple commodities like cod (fish), grain, fur, and timber. Thus, implementing the Staple Thesis as an economic policy, in the late 1900s, Canada started exporting these commodities, and today, forestry products such as wood pulp, softwood lumber, and newsprint are some of its major exports. However, in the 21st century, the export of processed and manufactured goods has replaced much of the earlier export of raw materials. Crude oil and automobiles now make up $22 \%$ and $13.8 \%$, respectively, of the total exports of Canada ${ }^{29}$. Some of Canada's imported goods consist of automobiles, automobile parts, and industrial machinery. After the NAFTA arrangement, the United States has been the leading trade partner of Canada (in terms of both exports and imports), followed by China and other countries such as Mexico, the United Kingdom, etc. The total annual export revenue of Canada exceeds its import expenditure. On the contrary, Bangladesh is a highly import-dependent country due to a lack of availability of technologically advanced equipment. Its major imports include machinery (such as computers), cotton, and mineral fuels (such as oil), which make up for 11.5\%, 10.8\%, and 8.7\%, respectively, of the total imports of Bangladesh ${ }^{30}$. Ready-made garments (RMG), jute, shrimps, and tea are some of the top exporting commodities of Bangladesh. Around $81 \%$ of export earnings come from the RMG industry; in fact, Bangladesh has left India behind in textile exports due to its Free Trade Agreements with many countries and the low-cost production availability in its country. Bangladesh's leading trade partner is China, followed by the United States and India.

Hence, the economic indicators of real GDP over time, life expectancy, sector performance, and trade performance successfully portray the in-depth economic condition of both nations and justify the reasons for Canada's higher level of economic growth.

\section{Solow Growth Model:}

After analysing the various economic indicators, the current and future economic performance of Canada and Bangladesh can be determined, however, there still isn't a concrete answer to the question imposed at the beginning of the paper: how did Canada become one of the wealthiest nations in the world in such a short time, while Bangladesh remains one of the least developed countries in the world? The Solow Growth model (also known as the Solow-Swan model), an economic model that determines the long-run economic growth, will be used in the contexts of both nations to develop the answer to the aforementioned question.

The Solow Growth model was constructed by Robert Solow (Prof. of economics at MIT and Nobel Memorial Prize winner) and Trevor Swan in $1956^{31}$. Set within the framework of neoclassical economics, this exogenous model explains long-run steady-state growth by considering the level of capital accumulation, population growth, savings rate, and productivity in an economy. The model is based on certain assumptions and variables:

The production takes place according to the linear homogeneous production function, i.e, a proportionate change in the factors of production, leads to the same proportionate change in output (known as constant returns to scale).

Production function: $\mathrm{Y}=\mathrm{F}(\mathrm{K}, \mathrm{L})$

Wherein, $\mathrm{Y}=$ output; $\mathrm{K}=$ capital stock (physical capital); L= labour (human capital) 
There are diminishing marginal productivities also present because adding inputs ( $\mathrm{K}$ and $\mathrm{L}$ ) will lead to a rise in output, but only to a certain point, after which an increase in the input will lead to a fall in output. Keeping one input constant while raising the other, will lead to a fall in productivity after an optimum point.

Population and workforce grow at the same rate- $n$

According to the GDP function: GDP $(\mathrm{Y})=\mathrm{C}+\mathrm{I}+\mathrm{G}+(\mathrm{X}-\mathrm{M})$, however, this model considers a closed economy and no role of government $(\mathrm{G}=0)$.

Therefore, $\mathrm{Y}=\mathrm{C}+\mathrm{I}$

$\mathrm{C}=\mathrm{Y}-\mathrm{I} \quad$ (Consumption= Output - Investment $)$

Considering everything in per worker terms for useful interpretations:

$\mathrm{y}=\mathrm{Y} / \mathrm{L}$ (output per effective worker)

$\mathrm{k}=\mathrm{K} / \mathrm{L}$ (capital per effective worker or capital-labour ratio)

$\mathrm{c}=\mathrm{C} / \mathrm{L}$ (consumption per effective worker)

Output per effective worker can be expressed as a function of capital per effective worker, therefore, per-worker production function: $\mathrm{y}=\mathrm{f}(\mathrm{k})$

All consumers in an economy allocate their incomes towards saving and consumption.

Therefore, $\mathrm{Y}=\mathrm{C}+\mathrm{S}$

$\mathrm{Y}=(\mathrm{Y}-\mathrm{I})+\mathrm{S}$ (substituting the value of $\mathrm{C}$ given above and then solving)

$\mathrm{I}=\mathrm{S}$ (Investment equals Savings)

Capital accumulates over time through investment and depreciates at a constant rate $\square$.

Gross investment must: i) replace worn-out capital, $\square \mathrm{k}$

ii) increase so that capital stock grows as the economy grows, nk

Therefore, $\mathrm{I}=(\square+\mathrm{n}) \mathrm{k}=$ break-even investment

Given that saving is a constant share of income,

$\mathrm{S}=\mathrm{sY}$ (where $\mathrm{s}$ is the saving rate)

$\mathrm{sY}=(\square+\mathrm{n}) \mathrm{k}($ since $\mathrm{S}=\mathrm{I})$

Putting this per-worker terms, s $\mathrm{f}(\mathrm{k})=(\square+\mathrm{n}) \mathrm{k}$

Therefore, saving per effective worker: $y=s \mathrm{f}(\mathrm{k})$

Steady-state: $\mathrm{y}, \mathrm{c}$, and $\mathrm{k}$ are constant over time and there is no productivity growth.

According to Figure 4 below, the only possible steady-state capital-labor ratio is $\mathrm{k}^{*}$. If $\mathrm{k}$ begins at some other level, for eg:

1. For $\mathrm{k}$ below $\mathrm{k}^{*}$, saving $>$ the amount of investment required to keep k constant, so $\mathrm{k}$ rises

2. For $\mathrm{k}$ above $\mathrm{k}^{*}$, saving < the amount of investment required to keep k constant, so $\mathrm{k}$ falls 


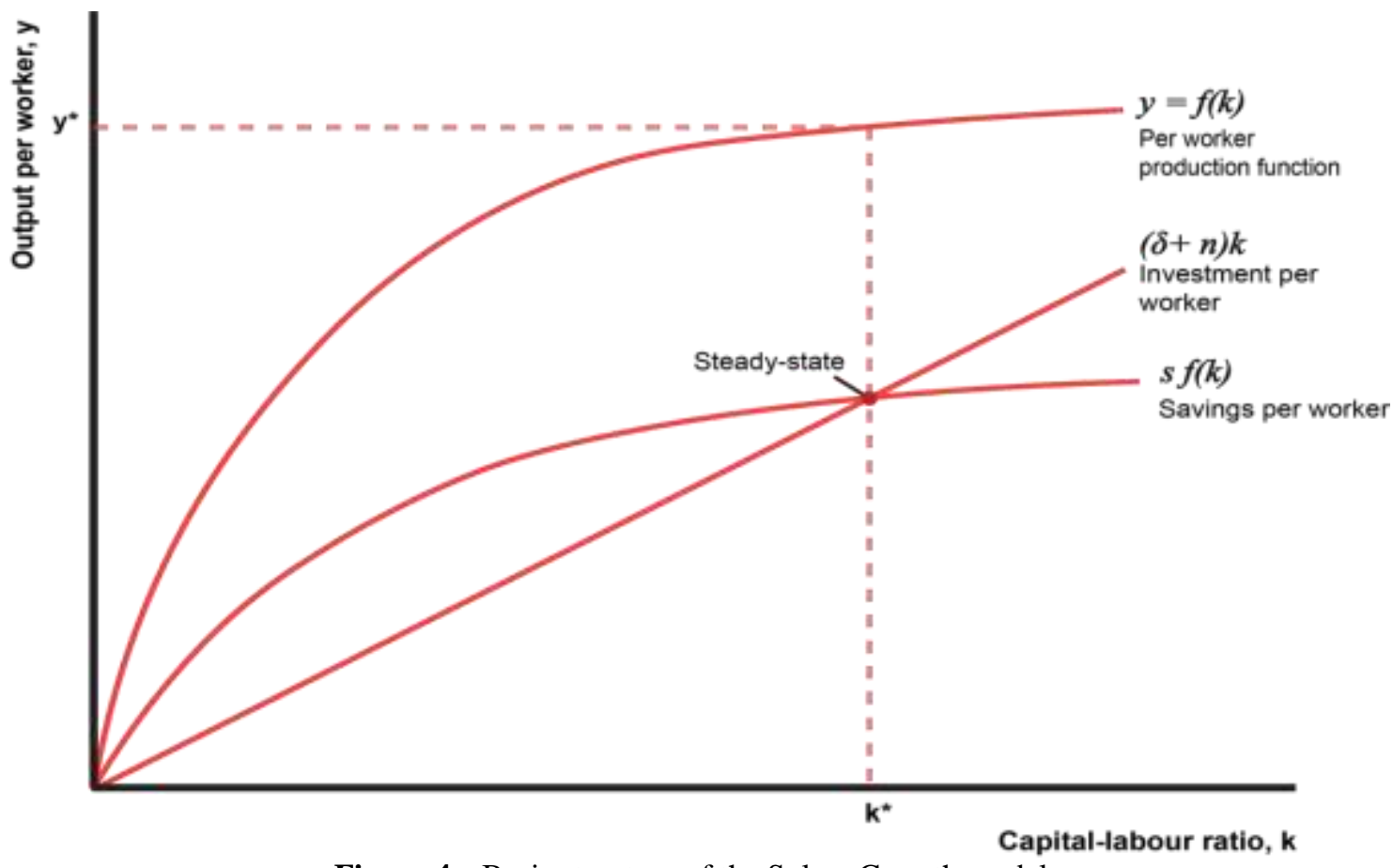

Figure 4:- Basic structure of the Solow Growth model.

In summary, since the Solow Growth model assumes the absence of productivity growth, the economy reaches a steady-state wherein the capital-labor ratio, output per worker, and consumption per worker remains constant. Hence, it leads to the evaluation of the savings rate, population growth, and productivity growth of a country, to determine ways to achieve long-run economic growth and higher living standards.

The savings rate is one of the fundamental catalysts of long-run economic growth, thus it becomes integral to analyse the data of the gross savings of both the countries from the past 25 years (shown in Figure 5 below). Gross savings is the gross national income less total consumption, plus net transfers. A rise in the savings rate is indicative of the availability of more funds for investment in both physical and human capital, which in turn is likely to raise productivity growth and capital stock. Bangladesh has a much higher value of gross savings than Canada, with a value pegged at $33.27 \%$ of the GDP in 2018, while Canada just had a value of $19.70 \%$ in 2018. Moreover, in 2017, Bangladesh was ranked number 9 in the list of countries that have the highest savings rate ${ }^{32}$. From the 1990s until 2012, Bangladesh witnessed a positive trendline; however, gross savings have been falling since then. Canada, on the other hand, has experienced a minorly fluctuating trend in its gross savings since the 1900s. The lowest rate that it has fallen to was $18.56 \%$ in 2009, right after the Global Financial Crisis. 


\section{GROSS SAVINGS (\% of GDP)}

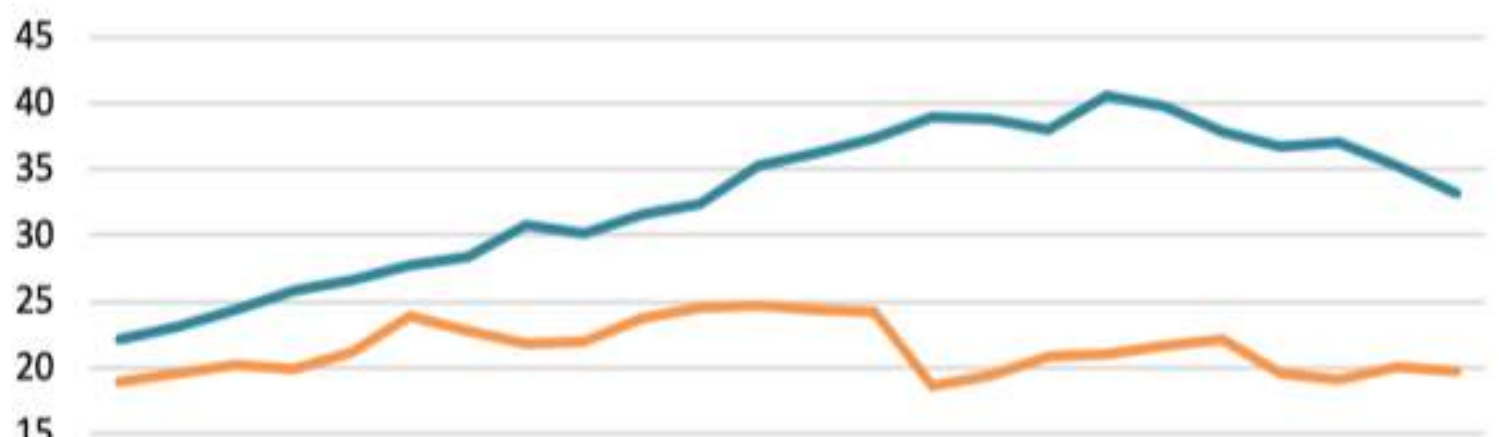

10

5

0

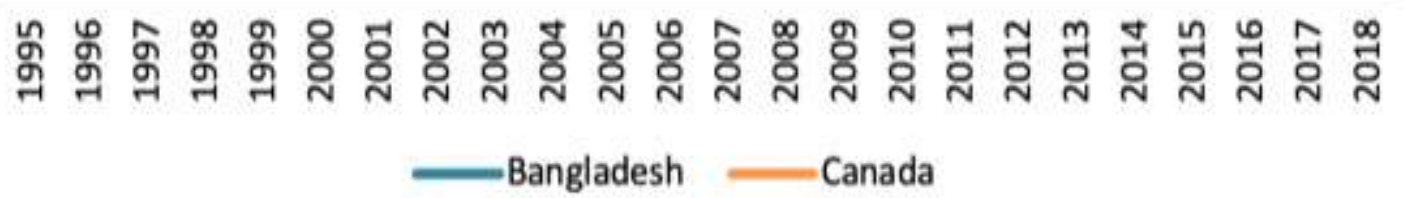

Figure 5:- Gross savings (\% of GDP), Canada and Bangladesh, 1995-2018.

Source: World Bank, Gross savings (\% of GDP), Canada and Bangladesh.

Population growth is another factor that influences long-run economic growth and so will be explored in the contexts of Canada and Bangladesh. A rise in population growth increases the steepness of the break-even investment curve in the Solow model (assuming a depreciation rate of 10\%) which leads to lower capital stock per worker. As demonstrated in Figure 6 below, Bangladesh has witnessed a steady decline in its population growth rate from $2.13 \%$ in 1995 to $1.14 \%$ in 2008 and after that, it has been relatively constant. This is because of a falling fertility rate from a high of $3.713 \%$ in 1995 to $2.036 \%$ in 2018 (World Bank, 2020). Additionally, the implementation of different preventive checks suggested by Malthus and Mill ${ }^{33}$ has also aided in Bangladesh's reduction in population growth rate. While Canada has experienced a comparatively volatile population growth rate, it has changed minutely with values varying between $0.74 \%$ and $1.40 \%$ over the past 25 years. Although Canada's population growth rate exceeded that of Bangladesh's in 2016, it has a lower total population (as mentioned initially in the paper) and the fertility rate of Canada has always been lesser too, with a difference of around $0.5 \%$. 




Figure 6:- Population Growth (annual \%), Canada and Bangladesh, 1995-2018. Source: World Bank, Population growth (annual \%), Canada and Bangladesh.

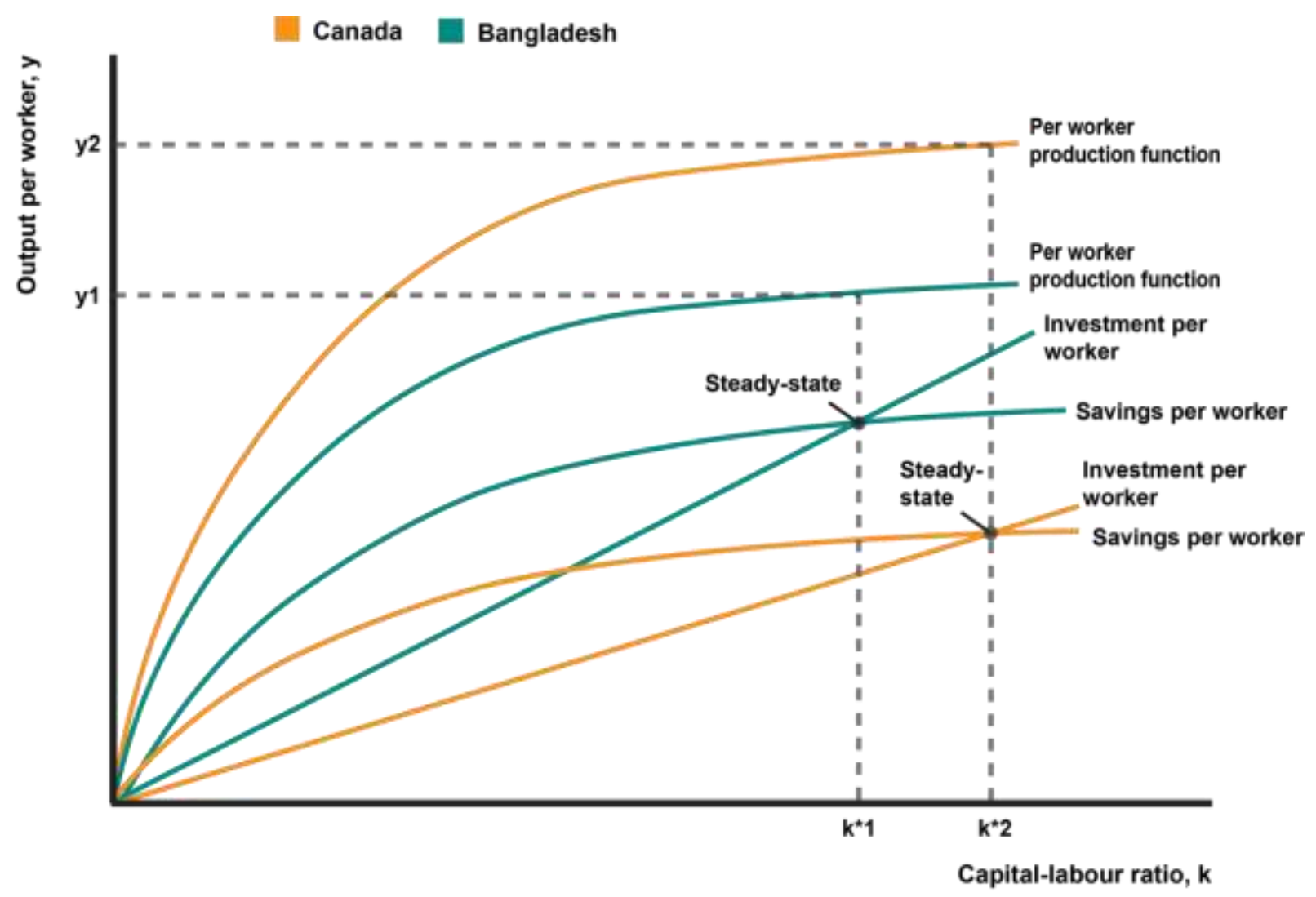

Figure 7:- Solow Growth models of Canada and Bangladesh (based on 2018's data)

The Solow Growth models of Canada and Bangladesh above in Figure 7 explain the disparity between the two countries' per capita GDP and level of development. The per-worker production function of Canada is higher than that of Bangladesh due to differences in physical capital and educational attainment. As mentioned in the economic 
profile earlier, Bangladesh has a shortage of physical capital like machinery and thus, imports it from other countries. While Canada has greater capital stock due to higher investments and lower savings. In 2016, the cumulative educational attainment of Canada stood at $25.8 \%$ whereas Bangladesh's was far below, at around $8.5 \%$ only.

According to Figure 5, savings per worker for Canada will be lower than that for Bangladesh as the gross savings (\% of GDP) of Bangladesh are higher. This might be because poor countries tend to save more; a higher saving rate is an indication of low investments, low consumption, low living standards, and hence lower per capita GDP. On the contrary, Canada's lower gross savings might mean greater investments, consumption, and thus higher economic growth. Consumption per worker is determined by the difference between per worker production function and savings per worker, i.e $\mathrm{f}(\mathrm{k})-\mathrm{sf}(\mathrm{k})=$ consumption per worker. At the steady-state level and along every point on the two curves, the consumption per worker is higher in Canada than in Bangladesh, which is connotative of Canada's higher living standards and better quality of life.

The break-even investment curve of Bangladesh is steeper because of its high population and high fertility rate, however, the steepness has reduced over time due to a falling population growth rate. Whereas due to a rise in population growth, Canada's break-even investment curve has become steeper over time, but it is relatively flatter as compared to Bangladesh today. A steeper investment per worker curve lowers the steady-state level of output and capital stock, which ultimately hinders growth and per capita GDP.

Bangladesh's rapid growth in GDP per capita after the 1990s (as shown in Figure 2) is called 'catching-up growth'. This occurs when a poor country grows faster to reach its steady-state through capital accumulation and this is represented by the initial rise of the savings per worker curve. On the other hand, a rich and developed country like Canada which has already experienced rapid growth before the 1900s might be experiencing 'cutting-edge growth' now due to its relatively slower rise in per capita GDP (as shown in Figure 1). This type of growth occurs when a country nears a steady-state level through idea accumulation because increasing capital stock will not lead to an increase in per capita GDP (diminishing returns).

According to the 'conditional convergence' theory, countries with initial dissimilar savings rates and population growth have different steady-state levels, but their growth rates eventually converge over time. However, this theory is false in the case of Bangladesh as it does not have the same institution as Canada, so a difference in political and economic factors will make it impossible for Bangladesh to match Canada's level of per capita GDP.

Overall, a higher output per worker of Canada (y2) at a higher capital-labor ratio $(k * 2)$ is likely to lead to higher long-run economic growth and higher per capita GDP.

\section{Conclusion:-}

The social infrastructure of Bangladesh, which consists of the dissimilarities between capital accumulation, productivity, and output per worker with Canada, is driven by differences in institutions and government policies. However, the policies integrated in Bangladesh's economy can be altered to achieve steady growth and economic development. Specifically, Bangladesh needs to focus on raising its total factor productivity (TFP) in order to grow economically.

Theoretically, there are many policies that can be strategized to help Bangladesh grow, but it is practically impossible to regulate all of them as conflicts of interest are likely to arise. Regardless, Bangladesh should focus on reducing the negative TFP effects of remittances by emigrant workers. The brain-drain effect has excessively spread, causing the already limited number of skilled and educated workers to migrate and work in countries outside of Bangladesh in search of better opportunities. The government could enforce stricter migration laws to control the rate of emigration in Bangladesh. In the Solow Growth Model, the per-worker production function of Bangladesh can be raised by investing in education and training. This will increase the number of skilled workers in the labour force, leading to higher TFP and will also compensate for the number of skilled labourers emigrating. A high rate of educational attainment would also mean people will be aware of family planning and usage of contraception, which will control population growth. Other problems of low fertility rate and low life expectancy at birth, which lead to population growth, can be solved by investments in healthcare. This will not only reduce death rates in the country and maintain a stable rate of population growth, but also make the labour workforce more productive and efficient, contributing to higher output per worker, and thus a higher per capita GDP. In the context of the Solow model, a 
reduction in population growth will further reduce the steepness of the break-even investment curve, extend the steady-state point further, and thus increase output per worker. As mentioned earlier, frequent flooding in Bangladesh has massive economic impacts on the economy, thus, the government could invest in infrastructure and build dams for protection. A good infrastructure is important for a country, it attracts foreign investments too. In comparison to Canada, Bangladesh can never attain the same level of per capita GDP due to its unstable government and political struggles. The corruption level in Bangladesh is too high which hinders its economic growth; to achieve a rise in TFP, a well developed political system is imperative.

In summation, Bangladesh is changing and gradually achieving growth and has prospered significantly in the 21 st century; however, it remains quite behind Canada due to numerous problems pertaining to population growth, investments, corruption, natural disasters, and weak macroeconomic stability. Policymakers and practitioners of development need to implement policies that lead to a sound macroeconomic growth of Bangladesh and help millions of its citizens escape poverty and have a better quality of life. On the other hand, Canada is one of the most developed economies in the world and is likely to further grow economically as predicted by the Solow Growth model.

\section{Bibliography:-}

1. Rahman, A. (2020). Bangladesh Liberation War, 1971 [Ebook]. Columbus. Retrieved from http://www.astronomy.ohio-state.edu/ nahar/cv/bdliberation-essay8.pdf

2. Canada's Long, Gradual Road to Independence. (2020). Retrieved 30 June 2020, from https://www.history.com/news/canada-independence-from-britain-france-war-of-1812

3. Multiculturalism | The Canadian Encyclopedia. (2020). Retrieved 30 June 2020, from https://www.thecanadianencyclopedia.ca/en/article/multiculturalism

4. Canada Population 2020 (Demographics, Maps, Graphs). (2020). Retrieved 30 June 2020, from https://worldpopulationreview.com/countries/canada-population/

5. Branch, C. (2020). Archived - Canada's Tourism Vision - Canada's Tourism Vision. Retrieved 30 June 2020 , from https://www.ic.gc.ca/eic/site/095.nsf/eng/00002.html

6. Centre, U. (2020). The Sundarbans. Retrieved 30 June 2020, from https://whc.unesco.org/en/list/798/

7. Bangladesh Population 2020 (Demographics, Maps, Graphs). (2020). Retrieved 30 June 2020, from https://worldpopulationreview.com/countries/bangladesh-population/

8. Geography. (2020). Retrieved 30 June 2020, from https://www150.statcan.gc.ca/n1/pub/11-402x/2011000/chap/geo/geo-eng.htm

9. Democratic Republic of the Congo: Economy. (2020). Retrieved 30 June 2020, from https://globaledge.msu.edu/countries/democratic-republic-of-the-congo/economy

10. Canada - Economy. (2020). Retrieved 30 June 2020, from https:/www.britannica.com/place/Canada/Economy

11. Banking in Canada | The Canadian Encyclopedia. (2020). Retrieved 30 June 2020, from https://www.thecanadianencyclopedia.ca/en/article/banking

12. MorCan Direct - Toronto Mortgage Broker. (2020). Retrieved 30 June 2020, from https://morcandirect.com/thebank-of-canada-a-brief-history/

13. Competitiveness Rankings. (2020). Retrieved 30 June 2020, from http://reports.weforum.org/globalcompetitiveness-index-2017-2018/competitiveness-rankings/\#series=EOSQ087

14. Rahman, A. (2020). Bangladesh Liberation War, 1971 [Ebook]. Columbus. Retrieved from http://www.astronomy.ohio-state.edu/ nahar/cv/bdliberation-essay8.pdf

15. Bangladesh - Bangladesh since independence. (2020). Retrieved 30 June 2020, from https://www.britannica.com/place/Bangladesh/Bangladesh-since-independence

16. Overview. (2020). Retrieved 30 June 2020, from https://www.worldbank.org/en/country/bangladesh/overview

17. Banking in Bangladesh. (2020). Retrieved $30 \quad$ June 2020 , from https://en.wikipedia.org/wiki/Banking_in_Bangladesh

18. Bangladesh - Economy. (2020). Retrieved $30 \quad$ June 2020 , from https://www.britannica.com/place/Bangladesh/Economy\#ref343158

19. Economy - Canada - export, average, growth, economic growth, policy, sector. (2020). Retrieved 30 June 2020 , from https://www.nationsencyclopedia.com/Americas/Canada-ECONOMY.html

20. National Policy. (2020). Retrieved 30 June 2020, from https://en.wikipedia.org/wiki/National_Policy

21. (http://www.hydrant.co.uk), S. (2020). Canada : Economy | The Commonwealth. Retrieved 30 June 2020 , from https://thecommonwealth.org/our-member-countries/canada/economy 
22. Bangladesh Overview of economy, Information about Overview of economy in Bangladesh. (2020). Retrieved 30 June 2020, from https://www.nationsencyclopedia.com/economies/Asia-and-the-Pacific/BangladeshOVERVIEW-OF-ECONOMY.html

23. (2020). Retrieved 30 June 2020, from https://www.un.org/development/desa/dpad/wpcontent/uploads/sites/45/publication/ldc_list.pdf

24. Life Expectancy by Country and in the World (2020) - Worldometer. (2020). Retrieved 30 June 2020 , from https://www.worldometers.info/demographics/life-expectancy/

25. Does Economic Growth Raise Life Expectancy?. Market Research Blog. (2020). Retrieved 30 June 2020 , from https://blog.euromonitor.com/economic-growth-and-life-expectancy-do-wealthier-countries-live-longer/

26. Dimensions of Poverty Hub. Statcan.gc.ca. (2020). Retrieved 30 June 2020, from https://www.statcan.gc.ca/eng/topics-start/poverty.

27. Canada - Agriculture, forestry, and fishing. Encyclopedia Britannica. (2020). Retrieved 30 June 2020 , from https://www.britannica.com/place/Canada/Agriculture-forestry-and-fishing.

28. Staple Thesis. Investopedia. (2020). Retrieved $30 \quad$ June 2020 , from https://www.investopedia.com/terms/s/staple-thesis.asp.

29. Workman, D. (2020). Canada's Top 10 Exports. World's Top Exports. Retrieved 30 June 2020, from http://www.worldstopexports.com/canadas-top-exports/.

30. [11:31 PM, 6/30/2020] Arnav: Workman, D. (2020). Bangladesh's Top 10 Imports. World's Top Exports. Retrieved 30 June 2020, from http://www.worldstopexports.com/bangladeshs-top-10-imports/.

31. [11:32 PM, 6/30/2020] Arnav: Solow growth model. Pitt.edu. (2020). Retrieved 30 June 2020 , from https://www.pitt.edu/ mgahagan/Solow.htm.

32. [11:32 PM, 6/30/2020] Arnav: Top 10 Countries That Save the Most. Investopedia. (2020). Retrieved 30 June 2020, from https://www.investopedia.com/articles/personal-finance/022415/top-10-countries-save-most.asp.

33. [11:35 PM, 6/30/2020] Arnav: Mpra.ub.uni-muenchen.de. (2020). Retrieved 30 June 2020 , from https://mpra.ub.uni-muenchen.de/91216/1/MPRA_paper_90826.pdf. 